\title{
PELAKSANAAN KEBERLANJUTAN SISTEM IRIGASI EMBUNG JURANG DAO DI DESA MAS-MAS KECAMATAN BATUKLIANG UTARA KABUPATEN LOMBOK TENGAH
}

\author{
Etti Suriasih, I Putu Sriartha, I Putu Ananda Citra \\ Jurusan Pendidikan Geografi \\ Universitas Pendidikan Ganesha \\ Singaraja, Indonesia \\ e-mail: ettisuriasih013@gmail.com, putusriartha@gmail.com, \\ ananda.citra@undiksha.ac.id
}

\begin{abstract}
Abstrak
Penelitian ini dilaksanakan di Desa Mas-Mas Kecamatan Batukliang Utara Kabupaten Lombok Tengah dengan tujuan: (1) mendeskripsikan pelaksanaan sistem irigasi Embung Jurang Dao, (2) mendeskripsikan daya dukung aspek geografi terhadap irigasi Embung Jurang Dao, dan (3) mendeskripsikan keberlanjutan sistem irigasi Embung Jurang Dao. Rancangan penelitian yang digunakan adalah rancangan penelitian deskriptif. Penentuan informan dalam penelitian ini dipilih secara purposive sampling dengan mengambil enam informan kunci. Pengumpulan data primer menggunakan metode observasi dan wawancara, sedangkan data sekunder menggunakan metode pencatatan dokumen yang selanjutnya dianalisis dengan metode deskriptif kualitatif. Hasil penelitian menunjukkan bahwa (1) pelaksanaan sistem irigasi Embung Jurang Dao meliputi pembagian air irigasi dilakukan secara proporsional dan bergiliran sesuai dengan jadwal yang telah ditetapkan oleh petugas, pemeliharaan sarana irigasi menjadi tanggung jawab langsung pemerintah yang dilakukan secara berkala dan rutin dan masyarakat dapat berpartisipasi di dalamnya, sedangkan kewajiban bagi petani pemakai air irigasi adalah menjaga, memelihara kebersihan saluran yang sifatnya gotong royong dan memberikan swinih (upah berupa hasil pertanian) kepada pekasih, selanjutnya sanksi bagi petani pemakai air yang melanggar dalam bentuk teguran, (2) daya dukung aspek geografi terhadap irigasi Embung Jurang Dao terdiri dari topografi yang curam, rata-rata curah hujan tahunan sebesar 3.294,5 $\mathrm{mm}$, dan keadaan tanah berjenis latosol yang tahan terhadap erosi, (3) keberlanjutan sistem irigasi Embung Jurang Dao terkatagori baik yakni dari aspek fisik menunjukkan kondisi jaringan dan fungsinya yang masih baik. Aspek sosial menunjukkan adanya institusi berupa Kelompok Tani Baru Bangun sebagai pengelola air irigasi bagi anggotanya dan penyelesaian konflik terkait irigasi embung dilakukan melalui musyawarah.
\end{abstract}

Kata kunci: Embung, aspek geografi, keberlanjutan. 


\title{
PELAKSANAAN KEBERLANJUTAN SISTEM IRIGASI EMBUNG JURANG DAO DI DESA MAS-MAS KECAMATAN BATUKLIANG UTARA KABUPATEN LOMBOK TENGAH
}

\author{
Etti Suriasih, I Putu Sriartha, I Putu Ananda Citra \\ Geography Education Department \\ Ganesha University of Education \\ Singaraja, Indonesia \\ e-mail: ettisuriasih013@gmail.com, putusriartha@gmail.com, \\ ananda.citra@undiksha.ac.id
}

\begin{abstract}
This research was conducted in Mas-Mas village, Batukliang district north central Lombok regency. The aim of this research (1) to describe the implementation of embung jurang dao's irrigation, (2) to describe the power support of the geographical aspects of irrigation Embung Jurang Dao, and (3) to describe the sustainability of Embung Jurang Dao's irrigation system. The design of this research was descriptive research design. Observation and interview method have used to the primary data collection, while for the secondary data, the researcher had used recording documents method then analyzed by qualitative descriptive method. The results of the research shown that (1) the implementation of irrigation system Embung Jurang Dao includes the division of irrigation water done by proportionally and take turns in accordance with the schedule set by the officer, maintenance of facilities irrigation becomes the direct responsibility of the government which is done in a manner periodic and routine and the community may participate in it, whereas the farmers as the user of the obligation of irrigation water have to be responsibility to maintain, to keep clean of irrigation channels that can be done by work together (gotongroyong) and give swinih (wages in the form of agricultural products) to the Pekasih, then the sanctions for the farmers who broke the rules in give warning to do not it again, (2) the carrying capacity of the geography aspect against the irrigation of Dew Bay consists of steep topography, the average annual rainfall is $3,294.5 \mathrm{~mm}$, and the type of the land is latosol which is resistant to erosion, (3) sustainability of the irrigation system of embung dah dao as well categorize shown from the physical aspect and it shown the condition of the network of the irrigation and its function is still good, while social aspect shown exsistence institution in the form of kelompok tani baru bangun as the manager of irrigation for its members and the settlement of conflicts related to embung irrigation is done through discussion.
\end{abstract}

Keywords: Embung, geographical aspects, sustainability. 


\section{PENDAHULUAN}

Indonesia sebagai salah satu negara yang memiliki berbagai sumber daya alam, termasuk salah satunya adalah tanah subur untuk usaha pertanian, perkebunan, dan lain-lain. Sektor pertanian selalu mendapat prioritas dalam pembangunan di Indonesia sejak pembangunan 5 tahun (Pelita) pertama (Ruslan 1996:1). Hal ini cukup beralasan, mengingat sektor pertanian merupakan komponen yang berperan penting dalam pembangunan nasional.

Pemerintah memberi

perhatian yang sangat serius terhadap masalah pertanian, baik melalui regulasi dan aksi yang lebih kongkret. Usaha pemerintah dalam rangka mengatasi permasalahan pada sektor pertanian di Indonesia tertuang dalam program yang disebut dengan "Nawa Cita". Program tersebut berisi sembilan program yang salah satu isinya memprogramkan percobaan lapang atau demplot pada tiap kabupaten guna meningkatkan produktivitas pertanian rakyat. Industri pengolahan pangan, peternakan, dan perikanan berdaya saing tinggi didorong untuk tumbuh (Kementerian Pertanian RI, 2015).

Program "Nawa Cita" yang diprogramkan pemerintah dalam rangka mengatasi permasalahan pada sektor pertanian di Indonesia sampai saat ini belum mampu membuat Indonesia berswasembada pangan. Ini terlihat dari tingginya tingkat impor bahan-bahan pokok terutama beras dari negara-negara tetangga. Hal ini juga diperparah oleh masalah gejala alam yang tidak menentu seperti musim panas yang berkepanjangan yang membuat lahan menjadi kering dan tanaman pertanian banyak menjadi mati. Selain itu, pertambahan penduduk yang terus-menerus meningkat dan relatif terbatasnya lahan pertanian mengakibatkan semakin lama lahan pertanian menjadi sumber daya yang langka serta masalah ketersediaan air untuk irigasi juga menjadi masalah serius dalam pertanian (BPS, 2016).

Pembangunan infrasrtuktur sumber daya air tentunya sangat dibutuhkan, khususnya pada daerah-daerah yang potensi airnya kurang. Pembangunan ini memberikan dukungan yang besar untuk pembangunan dalam bidang pertanian. Air sebagai sumber daya dan faktor determinan yang menentukan kinerja sektor pertanian, karena tidak ada satu pun tanaman pertanian dan ternak yang tidak memerlukan air. Meskipun perannya sangat strategis, namun pengelolaan air masih jauh dari yang diharapkan, sehingga air yang semestinya merupakan sahabat petani berubah menjadi penyebab bencana bagi petani.

Masyarakat di Kecamatan Batukliang Utara umumnya dan Desa Mas-Mas pada khususnya berusaha meningkatkan produksi hasil pertanian serta mengatasi kekeringan, dengan cara yang paling murah, cepat dan efektif serta hasilnya langsung terlihat, yaitu memanfaatkan limpahan air hujan yang ditampung pada embung (onfarm reservoir). Embung merupakan waduk berukuran mikro di lahan pertanian (small farm reservoir) yang dibangun untuk menampung kelebihan air hujan di musim hujan. Air yang ditampung tersebut selanjutnya digunakan sebagai sumber irigasi suplementer untuk budidaya komoditas pertanian bernilai ekonomi tinggi (high added value crops) di musim kemarau atau di saat curah hujan makin jarang. Secara operasional sebenarnya embung berfungsi untuk mendistribusikan dan menjamin kontinuitas ketersediaan pasokan air untuk keperluan tanaman ataupun ternak di musim kemarau dan 
penghujan (Syamsiah dan Fagi, 1997).

Embung sudah melekat dengan kehidupan masyarakat tani di Desa Mas-Mas terutama dalam pelaksanaan usahataninya. Keberhasilan usahatani di Desa ini dapat dikatakan sangat ditentukan oleh adanya Embung Jurang Dao. Mengingat keberadaannya yang sudah cukup lama, peranannya yang cukup besar dalam mendukung keberhasilan pertanian di daerah ini maka dipandang perlu untuk mengkaji sistem pengelolaan sumberdaya air melalui embung yang dilaksanakan petani di Desa Mas-Mas. Dengan adanya embung untuk jaringan irigasi, maka penggunaan lahan di Desa Mas-Mas diusahakan secara intensif, mengingat air untuk pengairan dapat diusahakan sepanjang tahun dan akhirnya akan berpengaruh terhadap perubahan dan perbaikan struktur perekonomian penduduk.

Berdasarkan permasalahan yang telah diuraikan di atas maka dilakukan penelitian mengenai "Pelaksanaan Keberlanjutan Sistem Irigasi Embung Jurang Dao di Desa Mas-Mas Kecamatan Batukliang Utara Kabupaten Lombok Tengah"

\section{METODE}

Penelitian ini merupakan penelitian deskriptif, dengan teknik penentuan informan menggunakan informan kunci. Pengumpulan data primer menggunakan metode observasi dan wawancara sedangkan data sekunder menggunakan pencatatan dokumen, yang selanjutnya dianalisis dengan metode deskriptif kualitatif.
HASIL DAN PEMBAHASAN

\section{Pelaksanaan sistem irigasi Embung Jurang Dao di Desa Mas-Mas Kecamatan Batukliang Utara Kabupaten Lombok Tengah.}

Pelaksanaan sistem irigasi embung merupakan suatu proses pengelolaan air irigasi agar berfungsi optimal dibandingkan dengan tidak melakukan upaya pengelolaan yang baik terdiri dari pembagian air irigasi, pemeliharaan sarana irigasi dan kewajiban maupun sanksi bagi petani pemakai air irigasi yang melanggar.

Hasil penelitian terhadap pelaksanaan sistem irigasi Embung Jurang Dao menunjukkan bahwa secara umum pembagian air dilaksanakan dengan cara: (a) Secara proporsional (bila air normal) Dalam desain bangunan sudah ditetapkan agar air yang mengalir pada cabang saluran akan otomatis terbagi secara proporsional sesuai dengan luas areal masing-masing, maka pengoperasiannya menjadi sangat mudah dan tidak perlu mengatur-atur lagi, dan (b) Secara giliran (bila air kurang). Jika suatu saat debit air tidak cukup untuk mengairi seluruh areal lahan, maka pembagian air dapat dilakukan secara giliran. Lamanya pemberian air bagi tiap blok dilakukan secara bergiliran dan diatur agar sebanding dengan luas areal masing-masing dan sebelum kandungan air tinggal $80 \%$ atau tanahnya mulai hampir kering, blok tersebut sebaiknya telah mendapat jatah giliran air lagi. Selanjutnya jika debit air di sumber air sudah normal kembali, maka pembagian air dapat dikembalikan secara proporsional lagi. (wawancara pada tanggal 19 Agustus 2017). 
Terkait pemeliharaan sarana irigasi Embung Jurang Dao, Balai Wilayah Sungai Nusa Tenggara 1 (BWSNT 1) menyatakan bahwa Embung Jurang Dao masuk ke dalam jenis embung pemerintah. Embung pemerintah adalah embung yang dibangun di lahan milik pemerintah dan pemanfaatan airnya oleh seluruh rakyat yang dapat dijangkau dengan kisaran volume air 200.000-2 juta serta menjadi tanggungjawab langsung pemerintah jika terjadi kerusakan (BWSNT, 2008 ). Dari paparan di atas tampak jelas bahwa pemeliharaan sarana irigasi menjadi tanggung jawab langsung pemerintah yang tentunya disesuaikan dengan laporan dari pengamat pengairan setempat.

Berdasarkan hasil wawancara dengan pengamat pengairan (waker) Bapak Erka Adi (wawancara pada tanggal 19 Agustus 2017) bahwa secara umum pemeliharaan fisik dari Embung Jurang Dao menjadi tanggungjawab pemerintah Kabupaten Lombok Tengah lewat Dinas Pekerjaan Umum tergantung dari tingkat kerusakan dan urgennya kondisi embung. Meski demikian, petani pemakai air juga bertanggungjawab untuk memelihara dan memperbaiki bangunan embung sesuai dengan kemampuan mereka.

Kegiatan pemeliharaan yang dilakukan dapat dirinci sebagai berikut:

a) Pemeliharaan Berkala Pemeliharaan berkala merupakan kegiatan perawatan dan perbaikan yang dilaksanakan secara berkala dalam kurun waktu tertentu yang direncanakan dan dilaksanakan oleh Pengamat/UPT Pengairan Kecamatan Batukliang dan bekerja sama dengan Kelompok Tani Baru Bangun secara swakelola. Pelaksanaan pemeliharaan berkala dilaksanakan secara periodik sesuai kondisi jaringan irigasi. b) Pemeliharaan Rutin

Pemeliharaan ini merupakan kegiatan perawatan dalam rangka mempertahankan kondisi jaringan irigasi Embung Jurang Dao yang dilaksanakan secara terus menerus. Pemeliharaan rutin dilakukan oleh petani disepanjang saluran primer, sekunder dan tersier yang melalui daerah persawahan yang mendapat manfaat/menggunakan air irigasi dari saluran.

Selanjutnya kewajiban petani pemakai air irigasi embung berdasarkan hasil wawancara dengan juru pengairan (waker) Bapak Erka Adi (wawancara pada tanggal 19 Agustus 2017) menyatakan bahwa "kewajiban petani pemakai air irigasi adalah sebatas menjaga dan memelihara kebersihan saluran yang sifatnya gotongroyong di bawah naungan Kelompok Tani Baru Bangun secara berkala".

Pendapat lain disampaikan oleh Bapak Aqil selaku ketua Kelompok Tani Baru Bangun "kewajiban para petani pemakai air irigasi Embung Jurang Dao yaitu memberikan swinih (upah berupa hasil pertanian) kepada pekasih, misalnya pada musim tanam pertama para petani menanam padi maka secara otomatis yang diberikan adalah padi. Pemberian upah kepada pekasih oleh para petani disesuaikan dengan luas tanah yang dikelolanya dan bagus tidaknya hasil panen pada waktu tersebut.

\section{Daya Dukung Aspek Geografi Terhadap Irigasi Embung Jurang Dao di Desa Mas-Mas Kecamatan Batukliang Utara}

Hasil penelitian menunjukkan bahwa daya dukung aspek geografi fisik terhadap keberadaan Embung Jurang Dao di Desa Mas-Mas Kecamatan Batukliang Utara dari segi topografi untuk Kecamatan Batukliang Utara memiliki 
kemiringan lereng antara $15-40 \%$, (topografi landai sampai curam) dan wilayah yang curam adalah meliputi Desa Mas-Mas tempat lokasi Embung Jurang Dao karena wilayah ini berdekatan dengan lereng Gunung Rinjani (BPS Kabupaten Lombok Tengah, 2016). Hal ini juga sesuai dengan hasil observasi langsung di daerah penelitian, kemiringan lereng di daerah Embung Jurang Dao yang berada Desa MasMas tepatnya di Dusun Senurus yaitu berada pada topografi landai dengan model tampungan air berbentuk seperti huruf $\mathrm{V}$, dan berada lebih tinggi dari daerah alirannya. Berdasarkan keadaan topografinya tersebut, maka air yang ada pada Embung Jurang Dao dapat dialirkan secara gravitasi pada lahan-lahan pertanian disekitarnya atau dengan sistem buka tutup sesuai kondisi airnya.

Sesuai dengan uraian di atas, tentunya sesuai dengan syarat mendirikan embung seperti yang dikemukakan Departemen Pekerjaan Umum (2008:11), yakni bertopografi curam atau bertopografi landai, sehingga air hujan dan air suplesi lainnya seperti sungai, bendungan yang ada di sekitarnya dapat mengalir ke daerah tersebut, jika pemanfaatannya untuk irigasi maka harus lebih tinggi dari daerah alirannya, oleh karena itu embung cocok di bangun di daerah ini.

Selanjutnya dari segi curah hujan untuk mendirikan embung yang ada di Provinsi NTB adalah memiliki curah hujan rata-rata tahunan di atas $1.100 \mathrm{~mm}$ (Dinas PU, 2008). Berdasarakan data curah hujan Desa Mas-Mas dari Dinas Pertanian, diketahui rata-rata curah hujan tahunan sebesar $3.294,5 \mathrm{~mm}$. Berkaca dari data curah hujan Desa Mas-Mas tersebut dan syarat-syarat mendirikan embung secara teoritis, maka embung cocok dibangun di daerah ini. Kemudian dari segi keadaan tanah, hasil penelitian menunjukkan bahwa jenis tanah di Desa Mas-Mas adalah tanah latosol. Tanah latosol merupakan tanah yang cocok dimanfaatkan untuk pertanian dan perkebunan, sehingga Desa Mas-Mas merupakan daerah yang tergolong subur. Selain itu juga, tanah latosol merupakan tanah yang mempunyai ciri atau karakteristik yang cukup baik bagi keberadaan bangunan embung antara lain; liat, berdebu, kandungan pasirnya sangat sedikit, daya tahan air cukup baik, dan tahan terhadap erosi. Kandungan yang tinggi dari tanah liat yang mengembang, menjadikan tanah sangat lengket ketika basah dan sangat keras ketika kering. Ketika tanah itu basah, permeabilitasnya terhadap air sangat rendah dan sukar pecah. Dengan demikian maka keadaan tanah diwilayah Desa Mas-Mas mendukung keberadaan Embung Jurang Dao. Sehingga jika dihubungkan antara syarat keadaan tanah untuk mendirikan embung secara teoritis dengan keadaan tanah di Desa Mas-Mas sebagai daerah penelitian, maka Embung Jurang Dao cocok dibangun di daerah ini.

\section{Keberlanjutan Sistem Irigasi Embung Jurang Dao Sebagai Salah Satu Sumberdaya Pertanian di Desa Mas-Mas Kecamatan Batukliang Utara}

Keberlanjutan sistem irigasi pada Embung Jurang Dao sesuai dengan hasil observasi langsung ke lokasi embung menunjukkan secara fisik embung ini masih berfungsi dengan baik, demikian juga aspek sosial masyarakat pendukung irigasi embung ini masih baik. Hal ini terlihat dari berbagai bangunan jaringan irigasi pada Embung Jurang Dao. Untuk melihat keberlanjutan sistem irigasi Embung Jurang Dao, akan dikaji menggunakan 2 aspek yaitu: 
1) aspek fisik

Dari aspek fisik menunjukkan

bahwa Kondisi jaringan yang dimaksud dalam penelitian ini adalah melihat kondisi fisik bangunan embung terdiri dari (1) pintu/kuri pembagi air irigasi, (2) tanggul, (3) papan duga muka air, dan (4) saluran sekunder. Pada umumnya kondisi jaringan irigasi akan menurun sejalan dengan waktu dan fungsi jaringanpun akan menurun mengikuti kondisi. Berdasarkan hasil penelusuran jaringan, seluruh jaringan irigasi dari Embung Jurang Dao masih dalam kondisi baik.

\section{Berdasarkan}

hasil

penelusuran yang dilakukan menunjukkan bahwa keberadaan Embung Jurang Dao dalam kondisi baik karena dilihat pada indikator yang diukur yaitu pintu-pintu atau kuri pembagian air irigasi menggunakan beton sehingga tahan terhadap tekanan air yang akan dibagi, sedangkan tanggul pada
Embung Jurang Dao juga dalam kondisi baik karena menggunakan beton, sehingga kondisi jaringan irigasi Embung Jurang Dao dari indakator pintu pembagi/kuri dan tanggul dapat dikatakan terkategori baik. Dengan demikian, tentunya hal ini dapat memperlancar distribusi pengairan dalam mengairi lahanlahan pertanian di Desa Mas-Mas khususnya di Dusun Senurus dan Dusun Antak-Antak.

Fungsi jaringan irigasi sangat erat kaitannya dengan kondisi jaringan yang ada. Hal ini tentunya juga tersangkut paut dengan upaya pemeliharaan jaringan irigasi, baik oleh pemerintah sebagai penanggung jawab langsung sarana pembangunan fisik embung dan juga para petani pemakai air. dengan variabel kondisi jaringan yaitu (1) pintu (kuri), (2) tanggul, (3) papan duga muka air, dan (4) saluran sekunder. Untuk lebih jelasnya dapat dirinci pada Tabel 0.1 berikut.

Tabel 0.1

Fungsi Jaringan Embung Jurang Dao

\begin{tabular}{|c|c|c|c|}
\hline $\begin{array}{l}\text { Variabel } \\
(1)\end{array}$ & $\begin{array}{l}\text { Indikator } \\
(2)\end{array}$ & $\begin{array}{l}\text { Kondisi } \\
\text { (3) }\end{array}$ & $\begin{array}{c}\text { Fungsi Keseluruhan } \\
(4)\end{array}$ \\
\hline \multirow[t]{3}{*}{$\begin{array}{l}\text { 1. Fungsi } \\
\text { Jaringan }\end{array}$} & Pintu/Kuri & Baik & $\begin{array}{l}\text { Secara Umum Fungsi Dari Pintu/Kuri Pada } \\
\text { Bangunan Bagi Di Embung Jurang Dao } \\
\text { masih dapat berfungsi dengan baik. Hal ini } \\
\text { dikarenakan pintu/kuri tersebut terbuat dari } \\
\text { besi sehingga tahan terhadap genangan } \\
\text { air embung. Hal ini juga tidak bisa terlepas } \\
\text { dari pemeliharaan yang dilakukan oleh } \\
\text { juru air. }\end{array}$ \\
\hline & Tanggul & Baik & $\begin{array}{l}\text { Sejauh ini untuk masalah tanggul dari } \\
\text { Embung Jurang Dao tergolong sangat } \\
\text { kuat karena terbuat dari beton. Sejak } \\
\text { dibangun pada tahun 1982, tanggul ini } \\
\text { tidak pernah mengalami kerusakan, } \\
\text { sehingga sampai sekarang masih } \\
\text { berfungsi dengan baik. }\end{array}$ \\
\hline & $\begin{array}{l}\text { Papan } \\
\text { Duga } \\
\text { Muka Air }\end{array}$ & Baik & $\begin{array}{l}\text { Alat ini merupakan alat untuk mengetahui } \\
\text { volume air masuk maupun air keluar, } \\
\text { sehingga efisiensi dari penggunaan air } \\
\text { Embung Jurang Dao dapat dipantau } \\
\text { melalui alat ini. Alat ini masih berfungsi }\end{array}$ \\
\hline
\end{tabular}




\section{Saluran Baik Sekunder}

Sumber: Analisis Data Primer, 2017

dengan baik. Hal ini terlihat dari warna dan angka yang tertera masih jelas terlihat.

Saluran sekunder dari Embung Jurang Dao masih berfungsi dengan sangat baik. Ini terlihat dari kelancaran air ke petak persawahan para petani. Saluran sekunder ini terbuat dari beton yang permanen. Pada bagian saluran ini sering ditumbuhi rumput liar dan semak belukar. $\mathrm{Hal}$ ini terjadi akibat musim yang terkadang tidak terus-menerus dilalui oleh air. Dengan demikian untuk menjaga agar distribusi air irigasi, para petani sering bergotong royong membersihkan saluran ini yang tentunya akan mengembalikan fungsinya seperti sedia kala.
Berdasarkan Tabel 0.1 di atas menunjukkan bahwa secara keseluruhan kondisi dan fungsi jaringan masih baik kecuali pintu/kuri pada salah satu "bangunan bagi" mengalami kerusakan yaitu kuri sebelah kanan. Hal ini disebabkan karena pintu/kuri tersebut belum pernah diganti sejak dipasang pada tahun 1982 silam. Hasil wawancara dengan juru pengairan (waker) Bapak Erka Adi (wawancara pada tanggal 19 Agustus 2017) menyatakan bahwa "sejak dipasang pintu/kuri pada saluran bagi tidak pernah diganti sejak tahun 1982 sehingga fungsinya semakin lama berkurang dan saat ini ada yang sudah tidak bisa berfungsi lagi, yang saat ini yang mengalami kerusakan di pintu kuri bagian kanan dari embung".

2) aspek sosial

Hasil penelitian dari aspek sosial menunjukkan adanya institusi pengairan yang ada di Desa MasMas berada di bawah Pemerintah Kecamatan Batukliang Utara. Kelompok tani di Desa Mas-Mas membawahi petani di dua dusun yang terairi oleh Embung Jurang Dao yakni dusun Senurus dan Antak-Antak, artinya anggota kelompok tani ini secara umum berasal dan berdomisili di dua dusun tersebut dengan luas areal pertanian 25 ha. Kelompok Tani "Baru Bangun" merupakan institusi formal yang mendapatkan pengawasan dan pembinaan dari pemerintah Kecamatan Batukliang Utara.

Kasus yang terjadi pada Kelompok Tani ini, tampaknya kurang melembaga di kalangan petani beririgasi embung. Hal ini disebabkan karena masyarakat tidak memerlukan hal-hal yang sifatnya formalitas seperti mengharuskan adanya AD/ART, adanya pertemuan rutin dan iuran rutin, namun lebih menekankan pada segi fungsional saja. Namun demikian, diakui atau tidak peran dari Kelompok Tani Baru Bangun di kalangan petani yang menjadi anggotanya cukup menonjol baik dalam menentukan pola tanam, jenis tanaman, pembagian air, sampai dengan penyelesaian konflik antar petani pemakai air irigasi embung.

Terkait pengairan yang tentunya dalam proses pembagian air irigasi embung kepada lahan pertanian para petani, pengelolaan air Embung Jurang Dao, masalah petugas, terkadang juga menimbulkan permasalahan. Seperti yang telah dijabarkan pada hasil penelitian bahwa dalam penyelesaian konflik lebih 
menekankan pada musyawarah untuk mencapai kesepakatan bersama secara adil. Penyelesaian konflik terkait air irigasi embung di Desa Mas-Mas tergolong sangat jarang mencuat ke permukaan. Sejauh ini masih dalam keadaan normal danpara petani merasa puas dengan pelayanan pengairan yang dilakukan oleh para petugas.

\section{SIMPULAN DAN SARAN}

Berdasarkan hasil dan pembahasan yang telah diuraikan mengenai pelaksanaan keberlanjutan sistem irigasi Embung Jurang Dao di Desa Mas-Mas Kecamatan Batukliang Utara Kabupaten Lombok Tengah, maka dapat disimpulkan sebagai berikut: (1) secara umum pelaksanaan sistem irigasi Embung Jurang Dao untuk irigasi pertanian yang ada di Desa Mas-Mas yaitu menggunakan sistem giliran dan proporsional yang terdiri dari pembagian air irigasi, pemeliharaan sarana irigasi dan kewajiban maupun sanksi bagi petani pemakai air irigasi yang melanggar telah berjalan dengan cukup baik, (2) daya dukung aspek geografi terhadap irigasi Embung Jurang Dao di Desa Mas-Mas Kecamatan Batukliang Utara terdiri atas topografi, curah hujan dan keadaan tanah. Ketiga aspek geografi ini memberi andil besar di dalam keberlanjutan sistem irigasi Embung Jurang Dao, dan (3) keberlanjutan sistem irigasi Embung Jurang Dao sebagai salah satu sumberdaya pertanian di Desa Mas-Mas Kecamatan Batukliang Utara dilihat dari dua aspek yaitu fisik dan sosial. Kedua aspek ini menunjukkan saling keterhubungan antar satu dengan yang lain. Hal ini mengingat betapapun kuat dan kokohnya bangunan embung yang telah dibangun permanen, tentu akan mudah rusak dan justru tidak berfungsi apabila aspek sosial yakni para petani pemakai air irigasi harus menjaganya dengan baik. Dengan demikian maka secara umum kedua aspek ini berpengaruh terhadap keberlanjutan irigasi baik disaat ini maupun dimasa datang.

Berdasarkan hasil penelitian, pembahasan, dan simpulan yang telah diuraikan di atas, maka dapat diajukan beberapa saran sebagai berikut. (1) bagi pemerintah Kabupaten Lombok Tengah hendaknya di dalam melaksanakan pemeliharaan jaringan irigasi agar lebih intensif, diharapkan melakukan upaya pencegahan terlebih dahulu ketimbang memperbaiki sarana bangunan fisiknya ketika sudah rusak parah dalam jangka waktu lama, (2) bagi masyarakat petani diharapkan dapat memaksimalkan kinerja irigasi embung di bawah kelompok taninya agar pertanian dimasa datang terus menunjukkan hasil yang lebih baik, dan (3) bagi peneliti lain yang mengkaji lebih dalam mengenai pelaksanaan keberlanjutan sistem irigasi embung, penelitian ini dapat dijadikan acuan untuk meneliti lebih dalam mengenai pelaksanaan keberlanjutan sistem irigasi dalam lingkup yang lebih luas.

\section{UCAPAN TERIMAKASIH}

Penelitian ini dapat diselesaikan berkat bimbingan dari berbagai pihak. Untuk ini pada kesempatan ini diucapkan terima kasih yang setulus-tulusnya kepada Rektor Universitas Pendidikan Ganesha, Dekan Fakultas Hukum dan IImu Sosial, Ketua Program Studi Pendidikan Geografi, staff dosen di Program Studi Pendidikan Geografi, Pembimbing Akademik, Pembimbing 1, Pembimbing 2, Penguji 1, dan Penguji 2, Dinasdinas pemerintahan di Kab. Lombok Tengah, Bapak Camat Batukliang Utara, Bapak Kepala Desa MasMas, Keluarga tercinta, situs internet penyedia data (BMKG dan BPS) dan 
rekan-rekan mahasiswa Program Studi Pendidikan Geografi angkatan 2012.

\section{DAFTAR PUSTAKA}

Badan Pusat Statistik. 2016. Kabupaten Lombok Tengah Dalam Angka. Praya: Biro Pusat Statistik Lombok Tengah.

Badan Pusat Statistik. 2016. Kecamatan Batukliang Utara dalam Angka. Praya: Biro Pusat Statistik Lombok Tengah.

\section{Balai Wilayah Sungai Nusa Tenggara I. 2008. Portofolio/Informasi Embung Jurang Dao, Lombok Tengah: Mataram.}

Direktorat Sungai Danau dan Waduk. 2006. Laporan Penyelidikan Geologi Dan Mekanika Tanah Kecamatan Batukliang Utara. Mataram: Indra Karya Cabang Mataram.

Pusposutarjo, Suprodjo. 2001. Pengembangan Irigasi. Yogyakarta: Direktorat Jenderal Pendidikan Tinggi Departemen Pendidikan Nasional.

Sriartha, I Putu. 2000. Buku Ajar Pengantar Geografi Pertanian. Singaraja: IKIP Negeri Singaraja.

Supadmo, Sigit. 2000. Keberlanjutan Sistem Irigasi Dalam Pembangunan Jangka Panjang Kedua (Studi Kasus di Pulau Jawa dan Bali). P3PK UGM.

Syamsiah, dan Fagi, 1997. Teknologi Embung, Sumber
Daya Air dan Iklim Dalam Mewujudkan Pertanian Efisien. Kerjasama Departemen Pertanian Dengan Perhimpunan Meteorologi Pertanian Indonesia (PERHIMPI).

Roerink, Gerbert. 1999. Sustainable Irrigated Agriculture and Water Management strategies in North Crimea Canal. United Nations: Water Resources Journal: 6-7. 